\title{
Kecerdasan Emosi sebagai Prediktor Kecenderungan Delinkuensi pada Remaja
}

\author{
Garvin \\ Program Studi Psikologi, Universitas Bunda Mulia, Jakarta \\ Email:garvin.goei@gmail.com
}

\begin{abstract}
ABSTRAK
Delinkuensi remaja merupakan perilaku remaja yang melanggar peraturan maupun norma yang berlaku. Delinkuensi tidak hanya bersifat merugikan diri sendiri, namun juga bisa merugikan orang lain atau keduanya. Ada dua faktor yang memengaruhi delinkuensi remaja, yakni faktor lingkungan dan faktor dari dalam diri remaja itu sendiri. Proses tumbuh kembang fisik maupun psikologis yang terjadi secara drastis pada remaja membuat remaja seringkali mengalami emosi-emosi negatif. Bila emosi-emosi negatif tersebut tidak disadari, hal ini membuat remaja lebih mudah terlibat dalam tindakan yang merugikan diri sendiri maupun orang lain. Kemampuan seseorang dalam menyadari emosi diri sendiri maupun orang lain serta mengelola emosi diri sendiri disebut sebagai kecerdasan emosi. Individu dengan kecerdasan emosi yang tinggi akan lebih mampu dalam mengelola emosi negatif serta mengekspresikannya dengan cara yang tidak merugikan pihak lain. Penelitian ini bertujuan untuk menguji hipotesis bahwa kecerdasan emosi dapat memprediksi kecenderungan delinkuensi. Penelitian ini menggunakan metode kuantitatif non-eksperimental, dengan partisipan penelitian berjumlah 149 orang yang merupakan siswa sekolah $X$ dan berada pada rentang usia remaja. Variabel bebas dalam penelitian ini merupakan kecerdasan emosi, sedangkan variabel terikat dalam penelitian adalah kecenderungan delinkuensi. Hasil uji regresi menunjukkan skor signifikansi $p=0,000<0,05$ yang menunjukkan bahwa kecerdasan emosi dapat memprediksi kecenderungan delinkuensi pada remaja secara signifikan. Penelitian ini menyimpulkan bahwa meningkatnya kecerdasan emosi memprediksi penurunan kecenderungan delinkuensi, dan sebaliknya.
\end{abstract}

Kata kunci: kecerdasan emosi, delinkuensi, remaja

\section{PENDAHULUAN}

Remaja merupakan salah satu tahapan dalam perkembangan manusia, yang merupakan masa peralihan dari kanak-kanak menuju dewasa. Dalam tahap perkembangan ini, remaja mengalami perkembangan fisik, kognitif, maupun psikososial yang terjadi secara drastis. Remaja memiliki tugas perkembangan yang disebut dengan identity versus identity confusion (Erikson dalam Papalia \& Feldman, 2012). Proses pencarian identitas ini membuat remaja senang melakukan eksplorasi untuk menemukan nilai-nilai yang dapat diadopsi sebagai bagian dari identitasnya (Steinberg, 2011).

Proses eksplorasi ini seringkali dilakukan tanpa pertimbangan yang matang. Hal ini membuat remaja menyukai untuk mencoba hal-hal baru, namun tidak memedulikan apakah hal tersebut bermanfaat atau tidak (Fatimah, 2006). Hal ini membuat remaja kadangkala melakukan tindakan-tindakan yang tidak sesuai dengan peraturan sosial maupun norma yang berlaku.

Perilaku remaja yang melanggar aturan maupun norma sosial seringkali disebut sebagai delinkuensi remaja. Dalam beberapa waktu belakangan ini, delinkuensi remaja dirasa semakin meresahkan. Secara fisik, remaja seringkali berkelahi dan melakukan tawuran. Misalnya kasus tawuran siswa SMK di Tangerang yang menyebabkan seorang siswa tewas, pada bulan November 2016 silam (Panduwinata, 2016). Selain itu, tawuran di Jakarta yang terjadi pada bulan September 2016 di Jakarta juga menewaskan seorang pelajar SMK (Fajar, 2016).

Tindakan melakukan tawuran hingga disertai dengan korban nyawa tentu merupakan perbuatan yang melanggar hukum. Kedua kasus tersebut hanya sedikit sekali contoh tawuran remaja yang 
merupakan bentuk delinkuensi. Selain tawuran, kasus keterlibatan remaja dalam zat-zat terlarang pun tak kalah memprihatinkan. Berdasarkan data yang dirilis oleh Badan Narkotika Nasional (dalam Tambun, 2016), diketahui bahwa sedikitnya ada 308 pelajar di DKI Jakarta yang terindikasi narkoba. Selain itu, berdasarkan riset yang dilakukan oleh Gerakan Nasional Anti Miras (dalam Kha, 2015) menemukan bahwa 23\% remaja Indonesia pernah mengonsumsi minuman keras. Belum lagi bentuk-bentuk delinkuensi lainnya seperti seks bebas, merusak fasilitas umum, melawan pihak otoritas, dan sebagainya. Delinkuensi jelas menjadi hal yang perlu diperhatikan.

Delinkuensi remaja dapat didefinisikan sebagai semua tingkah laku remaja yang menyimpang dari ketentuan yang berlaku dalam masyarakat (Sarwono, 2006). Perilaku delinkuensi bersifat merugikan, baik itu merugikan diri sendiri maupun orang lain, dan bila diketahui oleh petugas hukum dapat dikenai hukuman.

Jensen (dalam Sarwono, 2006) membagi perilaku delinkuensi remaja menjadi empat jenis, yaitu (1) kenakalan yang menimbulkan korban fisik pada orang lain, (2) kenakalan yang menimbulkan korban materi, (3) kenakalan sosial yang tidak menimbulkan korban di pihak lain, dan (4) kenakalan yang melawan status. Kenakalan yang menimbulkan korban fisik pada orang lain misalnya adalah berkelahi atau melakukan tawuran, sedangkan kenakalan yang menimbulkan korban materi misalnya merusak fasilitas umum yang tersedia. Kenakalan sosial misalnya adalah merokok, mengonsumsi narkotika, atau melakukan hubungan seksual di luar nikah. Sedangkan kenakalan melawan status, misalnya melawan guru ataupun orangtua (Sarwono, 2006).

Graham (dalam Sarwono, 2006) membagi faktor-faktor penyebab perilaku delinkuensi remaja menjadi 2 golongan, yaitu (1) faktor lingkungan, dan (2) faktor pribadi. Faktor lingkungan merupakan faktor penyebab delinkuensi remaja yang berasal dari luar diri remaja, seperti kemiskinan, gangguan lingkungan, migrasi, faktor sekolah, keluarga, atau gangguan dalam pengasuhan orang tua; sedangkan faktor pribadi merupakan faktor penyebab delinkuensi remaja yang berasal dari dalam diri remaja, baik itu faktor fisik maupun psikologis (Sarwono, 2006). Hasil studi dari Wijaya, Widiastuti, dan Nisfiannor (2010) menunjukkan bahwa pendidikan agama berkorelasi secara negatif dengan perilaku delinkuensi remaja.

Fatimah (2006) berpendapat bahwa perilaku delinkuensi merupakan bentuk pemberontakan yang merupakan bentuk ekspresi perubahan dari anak-anak menjadi remaja. Riset yang dilakukan oleh Ryan, Marshall, Herz, dan Hernandez (2008) menemukan bahwa kenakalan pada remaja dipengaruhi oleh kekerasan maupun pengabaian yang dilakukan oleh keluarga. Graham (dalam Sarwono, 2006) membagi faktor-faktor penyebab perilaku delinkuensi remaja menjadi 2 golongan besar, yaitu (1) faktor lingkungan, dan (2) faktor pribadi. Faktor lingkungan berasal dari hal-hal eksternal dari individu remaja, sedangkan faktor pribadi berasal dari hal-hal yang bersifat internal, seperti kepribadian, temperamen, kecerdasan, maupun kondisi fisik.

Kecerdasan emosi dapat didefinisikan sebagai kemampuan seseorang untuk mengidentifikasi proses emosi serta mengelolanya, baik pada diri seniri maupun orang lain (Goleman, 1995). Barnath (2016) menyatakan kecerdasan emosi seringkali didefinisikan sebagai kemampuan seseorang untuk mengenali perasaan diri sendiri dan orang lain, memotivasi, dan mengelola emosi dengan efektif. Kecerdasan emosi terdiri dari lima aspek, yakni: (a) mengenali emosi, (b) mengelola emosi, (c) memotivasi diri, (d) mengenali emosi orang lain atau berempati, dan (e) membina hubungan yang baik dengan orang lain (Goleman, 1995). 
Ada dua faktor yang memengaruhi kecerdasan emosi, yakni lingkungan keluarga dan lingkungan non-keluarga. (Goleman, 1995) Hal ini berarti, kecerdasan emosi bukanlah sesuatu yang bersifat warisan maupun genetik, melainkan hasil dari interaksi individu dengan sekitarnya. Hal ini mengindikasikan bahwa kecerdasan emosi bukan sesuatu yang bersifat pasti dan tidak bisa diubah, tetapi sebuah faktor psikologis yang bisa dibentuk melalui lingkungan.

Kecerdasan emosi merupakan kemampuan seseorang dalam menyadari perasaannya maupun orang lain (Goleman, 1995). Seringkali, remaja tidak mampu menyadari gejolak emosi yang timbul di dalam dirinya sendiri, sebagai akibat dari perubahan fisik maupun psikologis yang terjadi secara drastis ketika berada dalam tahap remaja. Hal ini membuat remaja tidak mampu mengendalikan perasaannya, terutama ketika menghadapi hal-hal yang sulit, sehingga membuat remaja mengekspresikan perasaan-perasaan negatif tersebut dalam hal-hal yang tidak benar.

Sebaliknya, bila remaja mampu mengenali perasaannya, maka remaja akan cenderung lebih mampu mengendalikan perasaan-perasaan negatif yang ia temui, sehingga remaja akan cenderung tidak mengekspresikan perasaan negatif tersebut ke dalam perilaku yang merugikan. Riset yang dilakukan oleh Rivers et al. (2013) menyatakan bahwa kecerdasan emosi menjadi faktor pelindung terhadap perilaku berisiko pada mahasiswa, seperti penggunaan zat terlarang, alkohol, maupun berkelahi. Di sisi lain, Edobor \& Ebiye (2017) menemukan bahwa kecerdasan emosi bisa memprediksi turunnya kecenderungan siswa sekolah menengah di Nigeria untuk terlibat dalam bullying dan perkelahian. Namun riset yang dilakukan oleh Bacon \& Regan (2016) menunjukkan bahwa kecerdasan emosi justru membuat perempuan berusia dewasa muda cenderung lebih delinkuen, dan kecerdasan emosi yang tinggi membuat perempuan mampu melakukan perilaku yang manipulatif. Hasil dari riset-riset tersebut menunjukkan bahwa kecerdasan emosi bisa membuat remaja terhindar untuk terlibat dalam penggunaan zat-zat terlarang maupun agresif, namun belum tentu menghindarkan remaja dari tindakan manipulatif. Di sisi lain, belum ada penelitian mengenai kecerdasan emosi terhadap kecenderungan delinkuensi pada remaja, yang nantinya bisa digunakan sebagai orangtua maupun guru dalam melihat potensi kenakalan pada peserta didik yang berusia remaja. Oleh karena itu, peneliti bermaksud meneliti kecerdasan emosi sebagai prediktor dari kecenderungan delinkuensi pada remaja.

\section{METODE PENELITIAN}

Penelitian ini merupakan penelitian kuantitatif non-eksperimental, dengan menggunakan analisis regresi untuk mengetahui hubungan satu arah antara variabel yang satu dengan variabel yang lainnya. Terdapat dua variabel dalam penelitian ini, yakni kecerdasan emosi yang menjadi variabel bebas dan kecenderungan delinkuensi yang menjadi variabel terikat.

\section{Latar dan partisipan penelitian}

Penelitian ini dilakukan di Sekolah Menengah Pertama X yang berada di Jakarta Utara. Pertimbangan peneliti dalam memilih sekolah ini karena terdapat banyak laporan tawuran yang terjadi pada siswa-siswa sekolah $\mathrm{X}$. Teknik sampling yang digunakan adalah accidental sampling. Dalam kasus ini, peneliti mengambil data dari seluruh pelajar yang hadir di sekolah pada saat peneliti datang ke sekolah tersebut. Partisipan berasal dari kelas 7 hingga 9, dan tidak terbatas pada jenis kelamin, suku bangsa, maupun agama. Total partisipan yang terlibat dalam penelitian ini adalah 149 orang. Adapun gambaran partisipan dari penelitian ini adalah sebagai berikut: 
Tabel 1. Gambaran partisipan berdasarkan jenis kelamin

\begin{tabular}{ccc}
\hline Jenis Kelamin & Frekuensi & Persentase \\
\hline Laki-Laki & 77 orang & $51,7 \%$ \\
Perempuan & 72 orang & $48,3 \%$ \\
\hline Total: & $\mathbf{1 4 9}$ orang & $\mathbf{1 0 0} \%$ \\
\hline Tabel 2. Gambaran partisipan berdasarkan usia \\
\hline Usia & Frekuensi & Persentase \\
\hline 11 tahun & 2 orang & $1 \%$ \\
12 tahun & 7 orang & $4 \%$ \\
13 tahun & 30 orang & $20 \%$ \\
14 tahun & 65 orang & $43 \%$ \\
15 tahun & 30 orang & $20 \%$ \\
16 tahun & 10 orang & $6 \%$ \\
17 tahun & 2 orang & $1 \%$ \\
Tidak mengisi kolom usia & 3 orang & $2 \%$ \\
\hline & Total: & $\mathbf{1 4 9}$ orang
\end{tabular}

Berdasarkan data-data di atas, maka terlihat bahwa perbandingan partisipan berjenis kelamin laki-laki dengan perempuan hampir seimbang. Selain itu, partisipan yang terbanyak berusia di antara 13 hingga 15 tahun.

\section{Pengukuran}

Variabel kecerdasan emosi diukur menggunakan skala kecerdasan emosi yang disusun berdasarkan teori Goleman (1991), terdiri dari lima dimensi: (a) mengenali emosi, (b) mengelola emosi, (c) memotivasi diri, (d) mengenali emosi orang lain atau berempati, dan (e) membina hubungan yang baik dengan orang lain. Alat ukur kecerdasan emosional terdiri dari 60 butir pernyataan mencakup butir positif atau favourable maupun butir negatif atau unfavourable, dengan pilihan respon yang berasal dari 1 (sangat tidak sesuai) hingga 5 (sangat sesuai). Uji reliabilitas dengan menggunakan konsistensi internal menunjukkan skor Cronbach's Alpha sebesar 0,884; yang menunjukkan bahwa alat ukur tersebut dapat dianggap reliabel untuk mengukur kecerdasan emosi.

Sedangkan variabel kecenderungan delinkuensi diukur menggunakan skala kecenderungan delinkuensi yang disusun berdasarkan teori dari Jensen (dalam Sarwono, 2006), yang membagi perilaku delinkuensi remaja ke dalam empat jenis, yaitu (1) kenakalan yang menimbulkan korban fisik pada orang lain, (2) kenakalan yang menimbulkan korban materi, (3) kenakalan sosial yang tidak menimbulkan korban di pihak lain, dan (4) kenakalan yang melawan status. Alat ukur kecenderungan delinkuensi terdiri dari 36 butir pernyataan yang terdiri dari butir positif/favourable maupun butir negatif/unfavourable. Masing-masing pernyataan diberikan respon yang berkisar dari 1 (sangat tidak sesuai) hingga 5 (sangat sesuai). Uji reliabilitas menunjukkan skor konsistensi internal sebesar 0,916; sehingga peneliti menyimpulkan bahwa instrument dapat dianggap reliabel untuk mengukur kecenderungan delinkuensi.

\section{HASIL DAN PEMBAHASAN}

Sebanyak 149 partisipan yang berusia remaja menjadi partisipan dari penelitian ini, terdiri dari 77 orang siswa yang berjenis kelamin laki-laki dan 72 orang siswa yang berjenis kelamin perempuan. Adapun gambaran kecerdasan emosional dari partisipan yang terlibat dalam penelitian ini terdiri dari 23,5\% yang memiliki skor kecerdasan emosi rendah, 55\% responden memiliki skor kecerdasan emosi yang tergolong sedang, dan $21,5 \%$ responden yang memiliki skor kecerdasan emosi yang tergolong tinggi. Penggolongan dari data kecerdasan emosi 
menggunakan persentil. Data yang bernilai lebih rendah dari persentil ke-25 dimasukkan ke dalam kategori rendah, data yang bernilai lebih tinggi dari persentil ke-75 dimasukkan ke dalam kategori tinggi, dan data yang berada di antaranya dimasukkan ke dalam kategori sedang. (tabel $3)$.

Tabel 3. Gambaran kecerdasan emosi partisipan

\begin{tabular}{|c|c|c|}
\hline Kategori & Frekuensi & Persentase \\
\hline Rendah & 35 orang & $23,5 \%$ \\
\hline Sedang & 82 orang & $55,0 \%$ \\
\hline Tinggi & 32 orang & $21,5 \%$ \\
\hline Total: & 149 orang & $100 \%$ \\
\hline
\end{tabular}

Pada skor kecenderungan delinkuensi, diperoleh hasil bahwa 26,8\% partisipan tergolong memiliki kecenderungan delinkuensi yang tinggi, 47,7\% partisipan memiliki kecenderungan delinkuensi yang sedang, dan 25,5\% partisipan memiliki kecenderungan delinkuensi yang tergolong rendah. Penggolongan kategori ini menggunakan persentil. Data yang lebih rendah dari persentil ke-25 digolongkan ke dalam kategori rendah, sedangkan data yang lebih tinggi dari persentil ke-75 digolongkan ke dalam kategori tinggi, adapun data yang berada di antara persentil ke-25 dan ke-75 dimasukkan ke dalam kategori sedang (tabel 4).

Tabel 4. Gambaran kecenderungan delinkuensi partisipan

\begin{tabular}{|c|c|c|}
\hline Kategori & Frekuensi & Persentase \\
\hline Rendah & 38 orang & $25,5 \%$ \\
\hline Sedang & 71 orang & $47,7 \%$ \\
\hline Tinggi & 40 orang & $26,8 \%$ \\
\hline Total: & 149 orang & $100 \%$ \\
\hline
\end{tabular}

Hasil uji korelasi antara variabel kecerdasan emosi dan kecenderungan delinkuensi menghasilkan skor $\mathrm{p}=0,000<0,05$; yang menunjukkan bahwa terdapat hubungan atau korelasi antara kecerdasan emosi dengan kecenderungan delinkuensi. Korelasi antara keduanya bersifat negatif, yang berarti kenaikan pada skor kecerdasan emosi berhubungan dengan penurunan pada skor kecenderungan delinkuensi, seperti yang tersaji dalam tabel 5.

Tabel 5. Hasil uji korelasi

\begin{tabular}{ccc}
\hline Variabel & Kecerdasan emosi & Kecenderungan delinkuensi \\
\hline Kecerdasan emosi & 1 & $-0,600$ \\
Kecenderungan delinkuensi & $-0,600$ & 1 \\
\hline
\end{tabular}

Pengujian dilanjutkan dengan melakukan uji regresi, dengan kecerdasan emosional sebagai variabel bebas dan kecenderungan delinkuensi sebagai variabel terikat, seperti yang tercantum dalam tabel 6 .

Tabel 6.Hasil uji regresi

\begin{tabular}{|c|c|c|c|c|c|}
\hline \multirow{2}{*}{ Model } & \multicolumn{2}{|c|}{ Unstandardized coefficients } & \multirow{2}{*}{$\frac{\text { Standardized coefficients }}{\text { Beta }}$} & \multirow[b]{2}{*}{ t } & \multirow{2}{*}{ Sig. } \\
\hline & B & Std. Error & & & \\
\hline (constant) & 4,730 & 0,301 & & 15,702 & 0,000 \\
\hline $\begin{array}{c}\text { Kecerdasan } \\
\text { emosi }\end{array}$ & $-0,733$ & 0,081 & $-0,600$ & $-9,098$ & 0,000 \\
\hline
\end{tabular}

Hasil uji regresi menyatakan bahwa kecerdasan emosi memprediksi kecenderungan delinkuensi secara signifikan dengan $\mathrm{F}(1,147)=82.767, \mathrm{p}<.05$ dengan $\mathrm{R}^{2}$ sebesar .360 . Model regresi yang 
dihasilkan adalah $\mathrm{Y}=4,730-0,733 \mathrm{X}$; di mana $\mathrm{Y}$ merupakan kecenderungan delinkuensi dan $\mathrm{X}$ adalah kecerdasan emosi. Nilai $\mathrm{R}^{2}$ sebesar .360 menandakan bahwa kecerdasan emosi dapat memprediksi kecenderungan delinkuensi sebanyak 36\%, sedangkan sisanya berasal dari faktor lain.

\section{KESIMPULAN DAN SARAN}

Berdasarkan data-data yang diperoleh dari penelitian, dapat disimpulkan bahwa kecerdasan emosional dan kecenderungan delinkuensi berhubungan atau berkorelasi secara negatif, dan kecerdasan emosi dapat menjadi prediktor dari kecenderungan delinkuensi pada remaja. Hal ini sesuai dengan pernyataan Graham (dalam Sarwono, 2006) bahwa delinkuensi remaja bisa berasal dari faktor lingkungan maupun internal. Selain itu, hasil penelitian ini juga selaras dengan Edobor \& Ebiye (2017) yang menemukan bahwa kecerdasan emosi bisa memprediksi menurunnya kecenderungan perilaku bullying maupun agresi pada siswa sekolah menengah.

Kecerdasan emosi merupakan salah satu faktor internal dari diri remaja yang bisa memprediksi kecenderungan delinkuensi. Hal ini karena kecerdasan emosi yang tinggi membuat remaja lebih sadar dan peka terhadap perasaannya sendiri maupun orang lain, sehingga remaja akan lebih banyak mencari pertimbangan sebelum melakukan perilaku yang merugikan yang berindikasi pada menurunnya kecenderungan delinkuensi. Sebaliknya, remaja dengan kecerdasan emosi yang lebih rendah membuat remaja lebih tidak menyadari perasaannya sendiri maupun orang lain, sehingga ia tidak terlalu banyak mencari pertimbangan sebelum melakukan tindakan yang merugikan, yang berdampak pada meningkatnya kecenderungan delinkuensi, selaras dengan temuan Rivers et al. (2013) yang menyatakan bahwa kecerdasan emosi bisa menjadi faktor pelindung terhadap perilaku yang berisiko. Saran bagi orangtua maupun pendidik, kecerdasan emosi dapat dijadikan pertimbangan dalam menilai kecenderungan delinkuensi dari remaja. Kecerdasan emosi yang tidak bersifat genetik dan dipengaruhi oleh lingkungan (Goleman, 1995) membuat kecerdasan emosi dapat dilatih. Hal ini bisa menjadi masukan bagi orangtua serta pendidik agar bisa lebih memerhatikan kecerdasan emosi, serta mengembangkannya, agar remaja lebih terhindar dari perilaku yang cenderung delinkuen.

Meskipun demikian, terdapat beberapa keterbatasan dalam penelitian ini. Misalnya, partisipan yang terlibat masih berasal dari satu sekolah yang sama, sehingga hasil dari penelitian ini masih belum dianggap adekuat untuk digeneralisasikan. Diperlukan sampel atau partisipan penelitian dengan jumlah yang lebih banyak dan tersebar di Jakarta agar hasil dari penelitian bisa digeneralisasi untuk remaja di Jakarta. Selain itu, kecenderungan delinkuensi yang diteliti di sini masih terlalu umum, hendaknya dapat diteliti lagi kecenderungan delinkuensi yang lebih mendetail seperti kecenderungan berperilaku seks bebas, kecenderungan menggunakan zat terlarang, maupun kecenderungan vandalism pada remaja. Bagi penelitian selanjutnya, disarankan untuk mengambil partisipan dengan jumlah yang lebih banyak dan tersebar. Selain itu, peneliti juga menyarankan untuk mencoba meneliti variabel lainnya yang dapat berkorelasi maupun memprediksi kecenderungan delinkuensi remaja, seperti kecerdasan sosial maupun kesejahteraan akademis.

\section{Ucapan Terima Kasih}

Rasa syukur dan ucapan terima kasih diberikan kepada Universitas Bunda Mulia yang sudah memberikan kesempatan kepada peneliti untuk melaksanakan penelitian ini. Selain itu, terima kasih juga dihaturkan kepada Kepala Sekolah maupun bagian Kesiswaan dari SMP X, tempat peneliti melakukan pengambilan data. Semoga penelitian ini bisa memberikan manfaat. 


\section{REFERENSI}

Bacon, A.M., \& Regan, L. (2016). Manipulative relational behaviour and delinquency: Sex differences and links with emotional intelligence. Journal of Forensic Psychiatry \& Psychology, 27(3), 331-348.

Barnath, I. (2016). Emotional intelligence. Women Police, 32(2), 16-17.

Edobor, O.J., \& Ebiye, D.M. (2017). Emotional intelligence as predictor of delinquent behaviours among secondary school students in Port Harcourt Metropolis, Rivers State Nigeria. European Journal of Research and Reflection in Educational Sciences, 5(2), 4859

Fajar, T. (2016). Tawuran dua SMK di Jakarta Utara menewaskan satu pelajar. Diakses dari http://news.okezone.com/read/2016/09/08/338/1485018/tawuran-dua-smk-di-jakarta-utaramenewaskan-satu-pelajar

Fatimah, E. (2006). Psikologi perkembangan: Perkembangan peserta didik. Bandung: Pustaka Setia.

Goleman, D. (1995). Emotional intelligence: Why it can matter more than IQ. NY: Bantam Books.

Kha (2015). 23 persen remaja Indonesia pernah konsumsi miras. Diakses dari http://news.detik.com/berita/2852915/23-persen-remaja-indonesia-pernah-konsumsimiras\%20pada\%2025\%20April\%202015

Panduwinata, A. (2016). Tragis, tawuran, pelajar di Tangerang tewas dibacok. Diakses dari http://wartakota.tribunnews.com/2016/11/21/tragis-tawuran-pelajar-di-tangerang-tewasdibacok

Papalia, D.E., \& Feldman, R.D. (2012). Experience human development $\left(12^{\text {th }}\right.$ ed.). NY: McGraw-Hill.

Rivers, S.E., Brackett, M.A., Omori, M., \& Sickler, C. (2013). Emotion skills as a protective factor for risky behaviors among college students. Journal of College Student Development, 54(2), 172-183.

Ryan, J.P., Marshall, J.M., Herz, D., Hernandez, P.M. (2008). Juvenile delinquency in child welfare: Investigating group home effects. Children and Youth Services Review, 30, 10881099.

Sarwono, S.W. (2006). Psikologi remaja. Jakarta: Rajawali Perkasa.

Steinberg, L. (2011). Adolescence $\left(9^{\text {th }}\right.$ ed.). NY: McGraw-Hill.

Tambun, L.T. (2016). Hingga Mei, 308 pelajar di DKI terindikasi narkoba. Diakses dari http://www.beritasatu.com/megapolitan/366398-hingga-mei-308-pelajar-di-dki-terindikasinarkoba.html

Wijaya, E., Widiastuti, N., \& Nisfianoor, M. (2010). Hubungan pendidikan nilai agama dengan perilaku delinkuensi pada remaja madya di sekolah menengah atas. Provitae, 4(1), 13-25. 